\title{
Molecular Analysis of Micropropagated Banana Variants (Musa spp. 'AAA') Using RAPD Markers
}

\author{
D. Shiddalingeswara ${ }^{1}$, D.P. Prakash ${ }^{2}$, Gajanana Kustagi ${ }^{2}$ and V. Nachegowda ${ }^{3}$
}

${ }^{1}$ Departemnt of Horticulture, University of Agricultural Sciences, GKVK, Bangalore, India

${ }^{2}$ College of Horticulture, Munirabad, Koppal-583 233, India

${ }^{3}$ University of Horticultural Sciences, Udyanagiri, Bagalkot- 587104, India

*Corresponding author

\section{A B S T R A C T}

In this study, RAPD fingerprinting has been carried out for variants selected from orchards growing with micropropagated Robusta banana (Musa spp. 'AAA') plants. After isolation

\section{Keywords}

Somaclonal variations, Robusta, RAPD, PCR, Random primers, Tissue culture

Article Info

Accepted: 04 June 2018 Available Online: 10 July 2018 of quality DNA and preliminary screening of random primers, fourteen arbitrary (10-mers) primers showing intense unambiguous and reproducible PCR amplification have been selected for study. Among them OPA-19 and OPC-03 showed only monomorphic bands while OPA-02, OPA-09, OPA-13, OPA-14, OPB-6, OPB-15, OPC-01, OPD-10, OPF-04 and OPF-12 primers showed polymorphic bands. A total of 123 amplified fragments were scored of which 53 were polymorphic in nature. In addition, in the dendrogram generated based on Ward's method of cluster analysis all morphological variants were grouped into a cluster, while other normal plant from orchard along with Robusta and Grand Naine pure lines formed another separate group. The genetic dissimilarity based on Squared Euclidean Distance ranged from 20-35 per cent between morphological variants and normal plant from orchard. The result showed that morphological variations in plants from orchard growing with micropropagated Robusta plants are somaclonal variations, which suggests that the commercial tissue culture units should use molecular means for testing genetic fidelity of tissue culture plants as a safety measure to avoid passing of off-type planting material to farmer. The primers selected in this study are useful in testing somaclonal variants.

\section{Introduction}

Bananas and plantains (Musa spp.) are important crops in the global fruit industry. In the world banana is grown in an area of 9 million hectares with total production of 92 million tones. In India banana occupies 20 per cent area under fruit crops and it supports livelihood of millions of people. The cultivar
Robusta of Cavendish subgroup (Musa spp. 'AAA') of banana is very popular because of high yield, wide market acceptability and high economic returns per unit area. Of late, banana is overtaking other fruit crops in production and productivity. Consequently, there is huge demand for planting material and major part of it is being met through micropropagation. Apart from the higher and faster multiplication 
rates, micropropagated banana plants have many advantages like regular availability of planting material, earliness, synchronized blooming and comparatively higher yields. However, increasing reports on array of morphological variations and high yield loss in micropropagated banana plants after several months of planting are the causes of concern for both growers and biofactories. There are a few possibilities for such morphological irregularities viz., nutrient deficiencies in soils (Smith and Drew, 1990), environmental conditions during hardening (Grillo et al., 1998) and occurrence of somaclonal variations due to features of the in vitro technique such as growth regulators and their concentrations, number of subcultures etc. (Rodrigues et al., 1998; Zaffari et al., 1998; Vidal and Garcia, 2000). In this regard, there is a need to identify varients in orchard and characterize them to ascertain whether it is due to somaclonal or mere morphological variation, to help former as well as tissue culture industry.

Several strategies can be used to assess the variability and to find out the genetic fidelity in in vitro derived clones, but most of them have their own limitations. Karyological analysis, for example, cannot reveal alterations in specific genes or small chromosomal rearrangements (Isabel et al., 1993). Biochemical markers like, isozyme markers provide a convenient method for detecting genetic changes (Carvalho et al., 1998), but are subject to ontogenic variations. Their use is also limited and only DNA regions coding for soluble proteins can be sampled. Presently, DNA based molecular markers like RAPD (Williams et al., 1990) are highly suitable, because of their simplicity, fast assay based on PCR, less cumbersome and it can analyze variations at many loci in minute quantities of DNA, even in closely related organisms such as near isogenic lines (NILs). The RAPD markers have been successfully employed in fingerprinting somaclonal variants (Damasco et al., 1996; Anitha et al., 1998; Walther et al., 1997; Martin et al., 1998; Martine et al., 2006; Vidya and Nair, 2002; Dougdoug et al., 2007) as well as assessment of genetic stability in long-term micropropagated bananas (Venkatachalam et al., 2007). In the present study, therefore, a survey was carried out to identify the morphological variants in orchards growing with micropropagated Robusta banana plants and also an effort has been made to characterize them using RAPD markers.

\section{Materials and Methods}

\section{Plant material}

In a survey of six orchards growing with micropropagated Robusta banana plants, 13 plants showing morphological variations (offtypes) were identified along with a normal yielding plant (Table 1; Figure 1). Cigar or newly opened leaf samples that were free from any probable pest and pathogenic damages were collected from all variant plants and a normal plant from orchard. The pure lines of Robusta and Grand Naine maintained at National Research Centre for Banana (NRCB), Trichy, India were collected and used as control (standard check for genotypes). The DNA was extracted using a protocol based on CTAB that was standardized for leaves having high carbohydrates, phenols and proteins (Prakash et al., 2002) with certain modifications.

\section{DNA isolation}

One gram of fresh leaf sample was ground in liquid nitrogen and suspended in $20 \mathrm{ml}$ of $2 \mathrm{X}$ CTAB extraction buffer [3\% CTAB, $100 \mathrm{mM}$ Tris (pH 8.0), 20 mM EDTA (pH 8.0), 1.4 M $\mathrm{NaCl}, 3 \%$ PVP and $0.1 \% \beta$-Mercaptaethanol], the suspension was incubated at $60^{\circ} \mathrm{C}$ for 45 
minutes, then it was cooled down to room temperature. An equal volume of chloroform: isoamylalcohol (24:1) was added, spun at $10,000 \mathrm{rpm}$ (revolution per minute) for 15 minutes at $4^{\circ} \mathrm{C}$, supernatant was collected into fresh tube and this step was repeated twice. Finally, supernatant was transferred into a fresh tube, 0.2 volume of $\mathrm{NaCl}$ was added, mixed gently, then one volume of ice-cold isopropanol was added, mixed gently and incubated overnight at $4^{\circ} \mathrm{C}$. Next day, contents were spun at $10,000 \mathrm{rpm}$ for 20 minutes at $4^{\circ} \mathrm{C}$ to pellet DNA, supernatant was discarded. The DNA pellet was washed twice with 70 per cent ethanol, air dried for 30 minutes and dissolved in $500 \mu \mathrm{l}$ of TE buffer $(10 \mathrm{mM}$ Tris $\mathrm{HCl}, \mathrm{pH} 8.0$ and $1 \mathrm{mM}$ EDTA, $\mathrm{pH}$ 8.0). Further, it was treated with $3 \mu \mathrm{l}$ RNase (10 $\mathrm{mg} / \mathrm{l})$ at $37^{\circ} \mathrm{C}$ for 50 minutes. Then it was extracted with equal volume of phenol, phenol: chloroform: isoamylalcohol $(25: 24: 1)$ and chloroform at $10,000 \mathrm{rpm}$ for 10 minutes at room temperature. Then the DNA was precipitated with 95 per cent chilled ethanol in the presence of $0.3 \mathrm{M}$ sodium acetate $(\mathrm{pH} 5.2)$ at $-20^{\circ} \mathrm{C}$ for 2 hours, pelleted at $10,000 \mathrm{rpm}$ for 20 minutes at $4^{\circ} \mathrm{C}$, washed twice with 70 per cent ethanol, air-dried for 30 minutes and resuspended in $250 \mu \mathrm{TE}$ buffer. The quality of DNA was assessed using both agarose gel $(0.8 \%)$ electrophoresis and 260/280 nm ratio using UV visible spectrophotometer (Shimadzu, USA) and quantity was calculated by using standard formula (OD $260 \mathrm{~nm} \mathrm{X} 50$ $\mu \mathrm{g} X$ Dilution factor/1000).

\section{Polymerase Chain Reaction (PCR)}

PCR amplification of genomic DNA was performed using random primers (10-mers; M/S Operon Technologies Ltd., USA). Amplification reaction was performed in a final volume of $25 \mu \mathrm{l}$ reaction mixture containing template DNA (25-30 ท́g), primer (5 picomoles), $\mathrm{MgCl}_{2}$ (2.00 mM), dNTP's (200 $\mu \mathrm{M}$; Bangalore Genei), Taq DNA
Polymerase (1 unit; Bangalore Genei) and 1X buffer [10 mM Tris $\mathrm{HCl}(\mathrm{pH} 8.8) ; 500 \mathrm{mM}$ $\mathrm{KCl} ; 15 \mathrm{mM} ; 0.1 \%$ gelatin; 0.05 per cent Tween-20 and $0.05 \%$ NP 40]. A drop of mineral oil (Sigma Chemical Co.) was overlaid on the reaction mixture to prevent the evaporation at high temperature. PCR was carried out in a thermal cycler (MJ Research, PTC 100) using programme profile consisting of an initial denaturation at $95^{\circ} \mathrm{C}$ for 5 minutes, followed by 45 amplification cycles each consisting denaturing for 1 minute at $94^{\circ} \mathrm{C}$, annealing at $35^{\circ} \mathrm{C}$ for 2 minutes and extension for 2 minutes at $72^{\circ} \mathrm{C}$ and final extension at $72^{\circ} \mathrm{C}$ for 10 minutes was also included in the program.

Amplified product was mixed with $6 \mathrm{X}$ loading buffer (30\% sucrose, $0.05 \%$ xylene cynol and $0.05 \%$ bromophenol blue) and loaded along with $500 \mathrm{bp}$ (base pair)/0.5 kb (kilo base pair) ladder (Genei, Bangalore) into 1.2 per cent agarose gel containing ethidium bromide $(0.001 \%)$. Electrophoresis was conducted at 50 volts for five hours and gel was photographed under UV light by using Alpha Digi Doc system (Herolab, Germany).

\section{Primer screening}

Primer screening was taken up using DNA isolated from a variant namely 'very dwarf', a normal Robusta plant from orchard and Robusta pure line from NRCB. Totally, 200 random primers (-10mers) were screened (OPA, OPB, OPC, OPD, OPE, OPF, OPH, OPJ, OPK and OPI series) including random primers from previous research studies on fingerprinting of somaclonal variation in micropropagated bananas. There was a negative control (with no template) and a positive control (using DNA of normal Robusta plant from field) reaction in all the amplifications carried out in the study to assess authenticity of amplification conditions. 
Gel scoring and analysis: Gels were observed closely for differences in amplification pattern between morphological variants and normal Robusta from orchard. Later, gels were scored for presence (1) or absence (0) of amplified bands and scored data was analyzed by using 'STATISTICA' software. Additionally, a dendrogram was developed for cluster analysis by using Wards method (Ward, 1963) and genetic dissimilarity matrix was generated using Squared Euclidean Distance.

\section{Results and Discussion}

In this study, the survey indicated that on an average 2.3 per cent of plants in the orchards growing with micropropagated Robusta banana plants showed morphological irregularities. Israeli et al., (1991) recorded variations up to 50 percent among micropropagated Cavendish bananas and linked the dwarf phenotypes to morphological anomalies viz., split fingers, mosaic leaves, deformed lamina, black pseudostem, choking, etc. Smith et al., (1999) identified an off type from micropropagated ladyfinger bananas that is characterized by its slow growth and poor bunch size. However, in this study using tips from those studies, plants showing morphological irregularities along with less or no yield compared to normal plants have been identified as morphological variants.

The genomic DNA isolated from leaves using the present protocol was of good quality (no shearing and free from protein and RNA contamination) and quantity (250-350 $\mathrm{ng} / \mu \mathrm{l})$ (data not shown). In preliminary round 50 random primers were selected that showed amplification out of 200 primers screened and in second round 14 were selected that showing intense, unambiguous and reproducible banding patterns for RAPD analysis (Table 2). There was no amplification in negative control. Intense, consistent and reproducible amplification patterns were observed in positive control and other samples showing that the amplification conditions were optimum and consistent. In gel scoring a total of 123 amplified fragments were scored from 14 primers of which, 53 were polymorphic in nature. The number of amplification fragments produced ranged from 5-19 with an average of 8.3 per primer and size of amplification fragments ranged from 250-2500 bp (Table 2). The primers OPA-19 and OPC-03 produced monomorphic fragments (Table 2; Figure not shown) and rest of the selected primers showed polymorphic amplification pattern indicating the existence of genetic difference in morphological variants compared to normal Robusta plant collected from orchard (Table 2; Figure 2). There were only two primers from previous studies (Damasco et al., 1996; Anitha et al., 1998; Walther et al., 1997; Martin et al., 1998; Martine et al., 2006; Vidya and Nair, 2002; Dougdoug et al., 2007) viz., OPA-2 and OPC-1, were useful in differentiating morphological variants and normal Robusta plant from orchard, while rest of them generated monomorphic amplification patterns. In previous studies, primers have been selected on variants of cultivar Grand Naine, Red and Williams and hence, it might be possible that all of them could not differentiate genetic variations in off types of Robusta cultivar. However, primers from present studies can be used in future molecular characterization of morphological variants in micropropagated Robusta banana plants.

The cluster analysis allowed a clear separation of variants and normal Robusta plant from orchard (Figure 3). In the dendrogram, there were two major clusters separated at a distance of 140 units. The major cluster one contained all 13 field identified morphological variants which were further sub grouped in to small clusters. The major cluster two contained normal Robusta plant from field, Robusta and Grand Naine clones of Cavendish group owing to the close genetic relationship within the Cavendish subgroup. Anitha (1998) noticed similar results in Cavendish subgroup of Musa spp. 
Table.1 List of plant materials used for RAPD characterization and Genetic Dissimilarity among them

\begin{tabular}{|c|c|c|c|}
\hline \multirow[t]{2}{*}{ Sl. No. } & \multirow{2}{*}{$\begin{array}{l}\text { Plant material with variable } \\
\text { characteristics }\end{array}$} & \multicolumn{2}{|c|}{ Genetic Dissimilarity (\%) } \\
\hline & & $\begin{array}{c}\text { Normal Robusta- } \\
\text { Orchard }\end{array}$ & $\begin{array}{c}\text { Robusta (NRCB, } \\
\text { Trichy) }\end{array}$ \\
\hline 1. & Choking & 29.00 & 26.00 \\
\hline 2. & Dwarf & 34.00 & 31.00 \\
\hline 3. & Streaking with bunchy appearance & 20.00 & 19.00 \\
\hline 4. & Rosette & 35.00 & 34.00 \\
\hline 5. & Tip Burn & 31.00 & 28.00 \\
\hline 6. & Foliage Mosaic & 32.00 & 29.00 \\
\hline 7. & Extra Dwarf & 34.00 & 31.00 \\
\hline 8. & Medium Dwarf with brown spots & 32.00 & 31.00 \\
\hline 9. & Extra dwarf plant with split pseudostem & 35.00 & 32.00 \\
\hline 10. & All foliage plant & 35.00 & 32.00 \\
\hline 11. & Small fruited & 33.00 & 30.00 \\
\hline 12. & Chlorophyll mutant & 31.00 & 28.00 \\
\hline 13. & Yellowing with burnt appearance & 24.00 & 25.00 \\
\hline 14. & Robusta (NRCB, Trichy, India) & 5.00 & 00.00 \\
\hline 15. & Normal Robusta-Field & 00.00 & 5.00 \\
\hline 16. & Grand Naine (NRCB, Trichy, India) & 11.00 & 8.00 \\
\hline
\end{tabular}


Table.2 Synthetic deoxyribonucleotide random (-10mer) primers used in present study for RAPD characterization

\begin{tabular}{|c|c|c|c|c|c|}
\hline $\begin{array}{l}\text { Primer } \\
\text { No. }\end{array}$ & $\begin{array}{c}\text { Nucleotide } \\
\text { sequence }\left(5^{\prime}-3^{\prime}\right)\end{array}$ & $\begin{array}{l}\text { No. of bands } \\
\text { amplified }\end{array}$ & $\begin{array}{l}\text { Monomorphi } \\
\text { c bands }\end{array}$ & $\begin{array}{l}\text { Polymorphi } \\
\text { c bands }\end{array}$ & 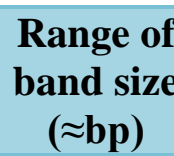 \\
\hline OPA-02 & TGCCGAGCTG & 10 & 08 & 02 & $500-1750$ \\
\hline OPA-09 & GGGTAACGCC & 12 & 04 & 08 & $500-2000$ \\
\hline OPA-13 & CAGCACCCAC & 05 & 4 & 1 & $700-1600$ \\
\hline OPA-14 & TCTGTGCTGG & 08 & 6 & 2 & $500-2000$ \\
\hline OPA-19 & CAAACGTCGG & 07 & 7 & 0 & $500-1500$ \\
\hline OPB-06 & TGCTCTGCCC & 10 & 6 & 4 & $450-2500$ \\
\hline OPB-10 & CTGCTGGGAC & 05 & 2 & 3 & $600-1000$ \\
\hline OPB-15 & CCAGGGTGTT & 10 & 8 & 2 & $300-2500$ \\
\hline OPC-01 & TTCGAGCCAG & 10 & 6 & 4 & $300-2300$ \\
\hline OPC-03 & GGGGGTCTTT & 05 & 5 & 0 & $600-1600$ \\
\hline OPD-10 & GGTCTACACC & 06 & 2 & 4 & $600-2300$ \\
\hline OPD-11 & AGCGCCATTG & 06 & 3 & 3 & $300-1500$ \\
\hline OPF-04 & GGTGATCAGG & 19 & 3 & 16 & $300-2500$ \\
\hline \multirow[t]{2}{*}{ OPF-12 } & ACGGTACCCC & 10 & 6 & 4 & $250-2000$ \\
\hline & Total & 123 & 70 & 53 & \\
\hline
\end{tabular}


Fig.1 A representation of normal and morphological variant plants collected from orchards growing with micropropagated Robusta banana plants used for RAPD characterization A)

Normal B) Dwarf variant; C) Rosette; D) Choking; E) Dwarf and F) Extra dwarf
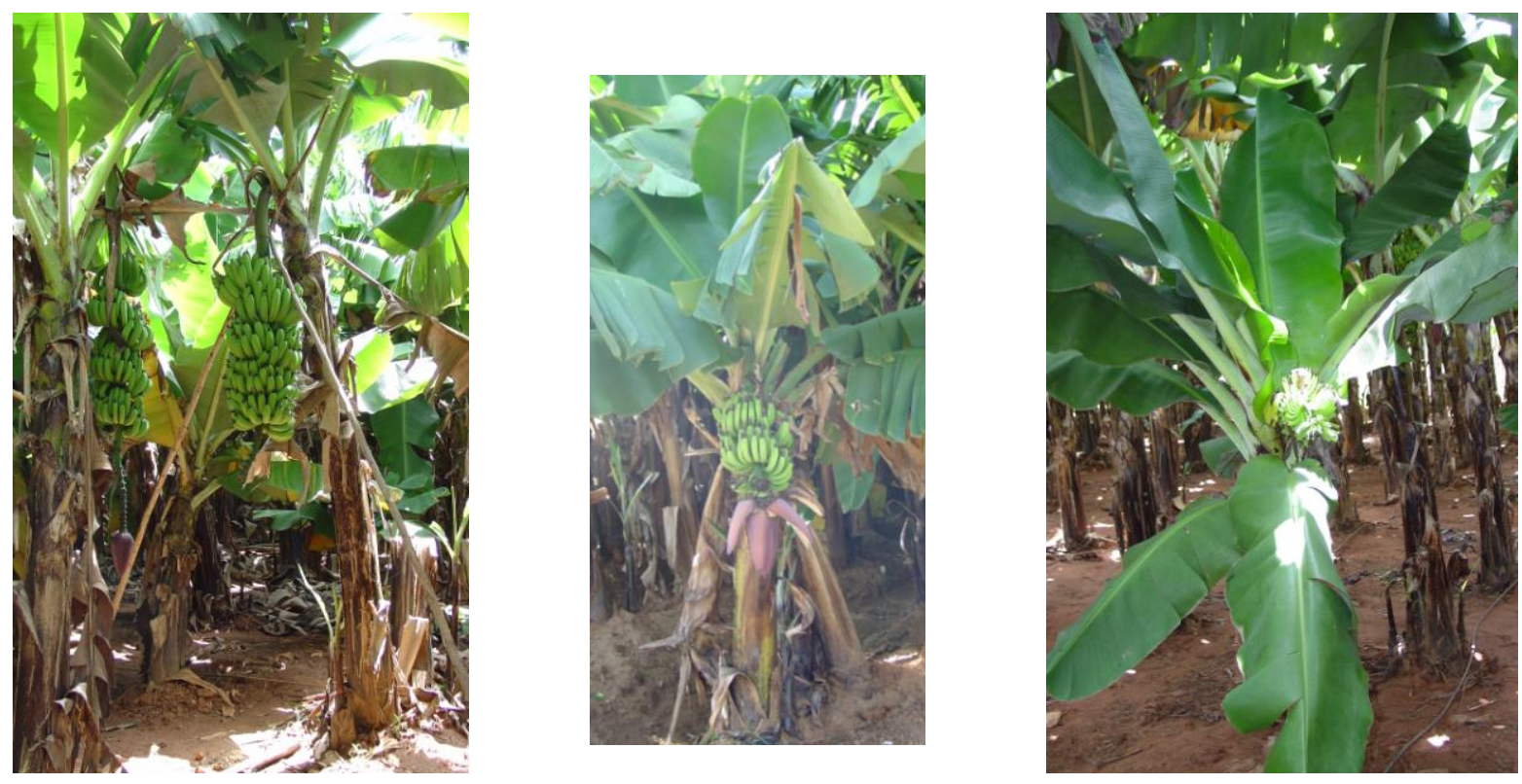

Fig.3 Genetic association among thirteen morphological variants, a normal plant from orchards growing with micropropagated Robusta banana plants and Robusta and Grand Naine pure lines

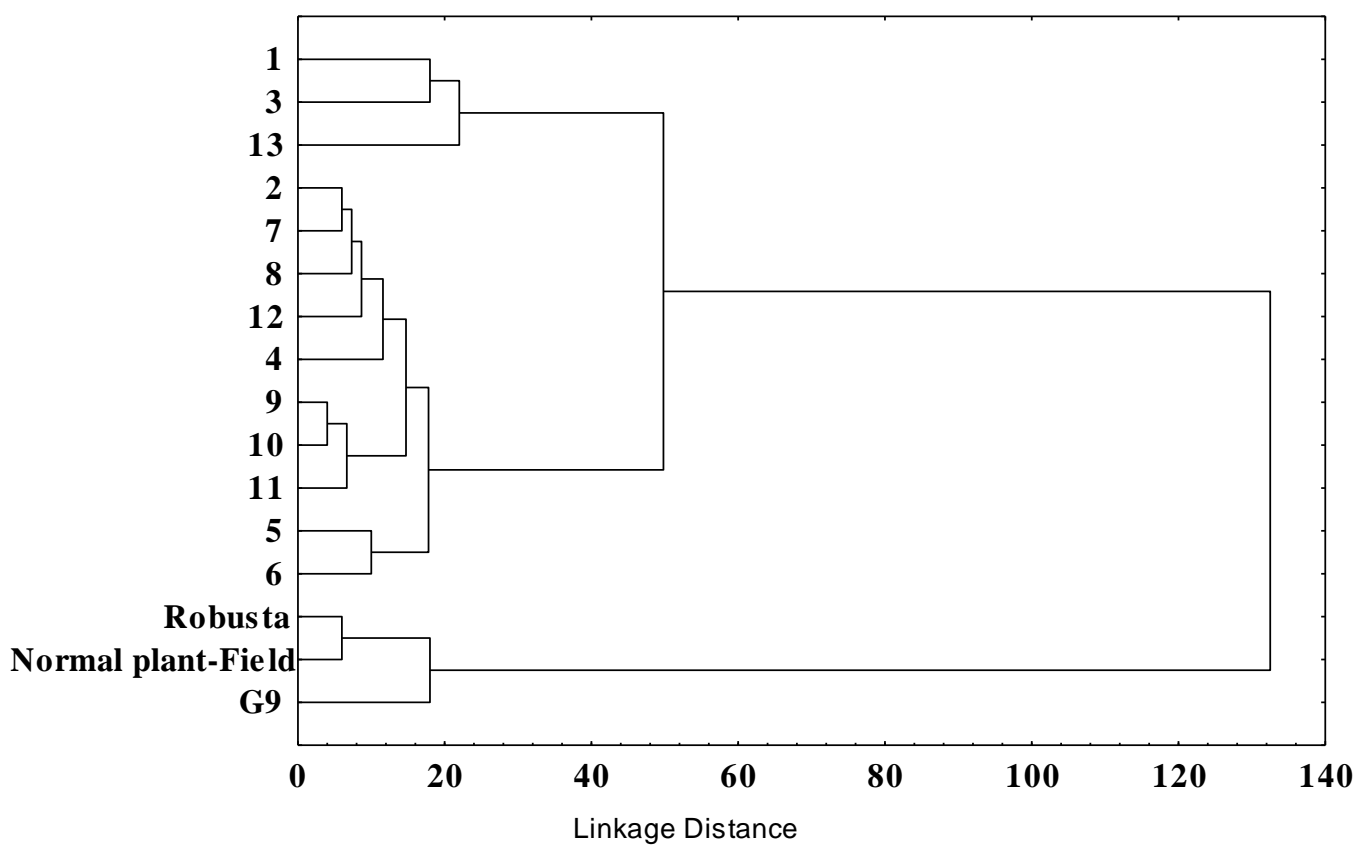


Fig.2 RAPD gel profiles of plant material used in the present study using various random primers [Legend: Lane1-16 remains same as in Table 1; +-positive control; -ve-negative control; M-500 bp ladder (Bands in vertical order-0.5, 1, 1.5, 2, 2.5, 3, 3.5, 4, 4.5, 5 kb)]

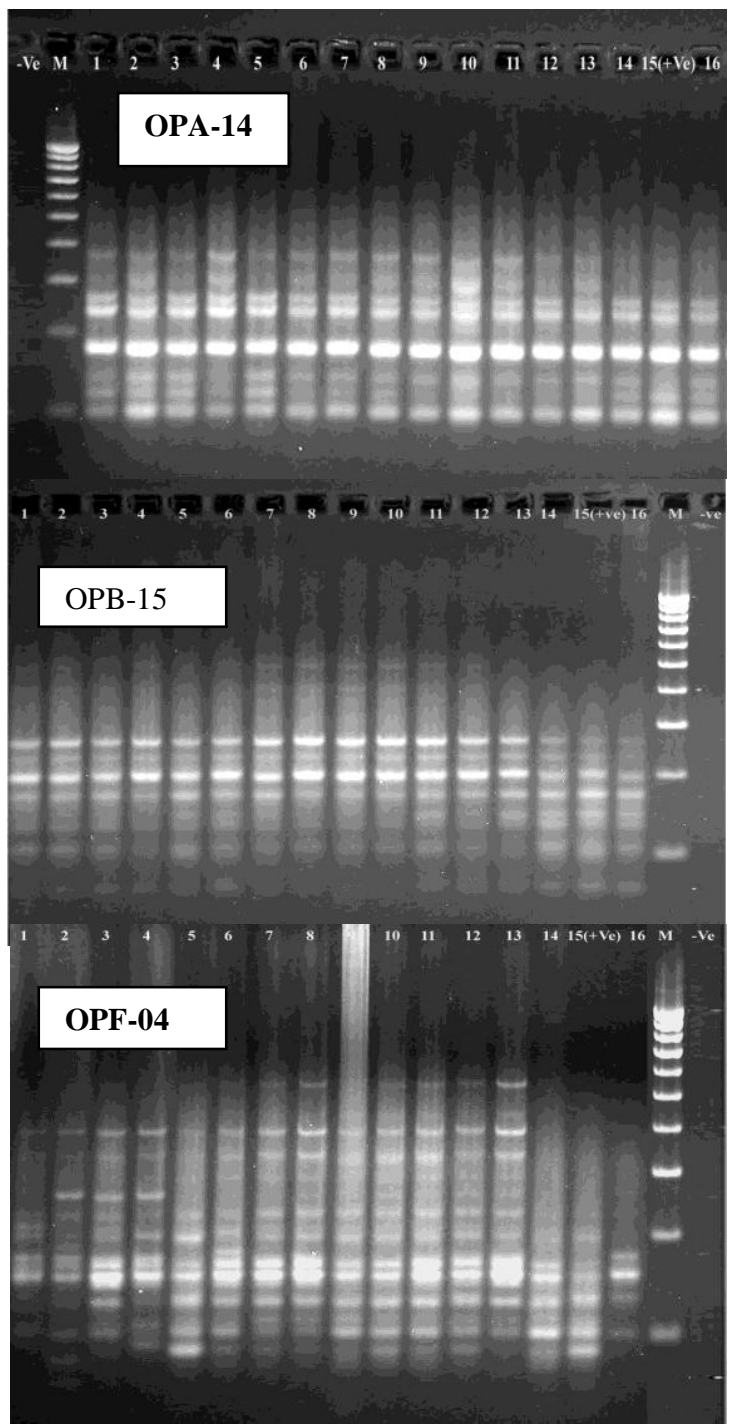

In this study, the Genetic Dissimilarity analysis showed 20-35 per cent dissimilarity between morphological variants and normal plant (Table 2).

There was $8 \%$ dissimilarity between the cultivars Grand Naine and Robusta pure lines. The morphologically normal plant from field was genetically dissimilar (5\%) to 'Robusta' pure lines from NRCB. However, that genetic variation in normal plant neither appeared morphologically nor affected fertility, which could be a novel source for crop improvement.

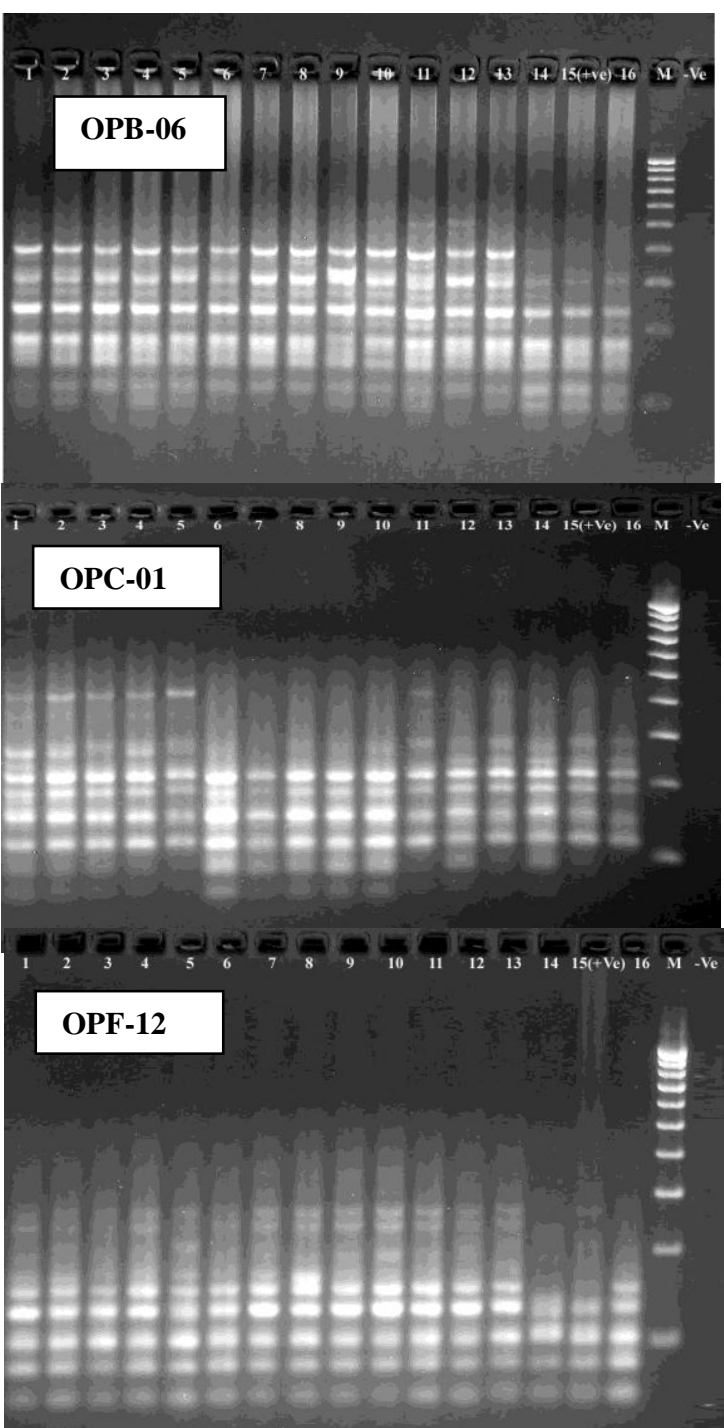

The results showed that morphological variations in plants collected from orchard growing with tissue culture Robusta banana plants are somaclonal variations. The genetic changes detected here may be due to culture conditions including excision of explants through subcultures and growth regulators. The molecular mechanisms underlying somaclonal variations have been attributed to chromosome breakage, single base changes, changes in copy number of repeated sequences and alteration in DNA methylation patterns (Kaeppler and Phillips, 1993). 
The polymorphisms in the amplification products may be either from changes in the sequences of the primers binding sites (e.g. point mutations) or changes which alter the size or prevent the successful amplification of the a target DNA (e.g. insertion, deletions, inversions). Rani et al., (1995) expressed similar opinion in genetic assessment of micropropagated Populus sp. Finally, this study suggests for the use of molecular markers for testing genetic fidelity of micropropagated banana plants at early stages to prevent loss of inputs, time and money to farmers. In addition, suggests the requirement of trained personnel for the purpose of quality control during nursery stage, who can apply the detection tools whenever applicable in a comprehensive manner. These measures enable the production of quality planting material, which can play a major role in the betterment of growing community and ultimately the national economy.

In conclusion, the molecular analysis of morphological variants of Cavendish group bananas from the farmers' orchards showed that an optimal detection of variants could be achieved using RAPD markers. These primers can be used by tissue culture industry in early identification of somaclonal variations in banana. In future, collection of large numbers of variants of a particular type and developing markers or primers for identification of each such variation needs to be carried out.

The authors are grateful to the Director, Department of Horticulture, Government of Karnataka for the financial assistance in the form of State Department Project.

\section{References}

Anitha, A.V., 1998, Characterization of banana and plantain using random amplified polymorphic DNA markers. Acta Hort., 490:113-119.
Carvalho, M. V. T. Derbyshire, E. Corder, M. P. Mendez, M. Z. and Neto, A. T., 1998, Isozyme and dissociated protein problems of normal plants and somaclonal variants of banana obtained by in vitro culture. Acta Hort., 490: 437-444.

Damasco, O. P. Graham, G.C. Henry, R.J. Adwins, S.W. Smith, M.K. and Godwin, I.D., 1996, Random amplified polymorphic DNA (RAPD) detection of dwarf off-types in micropropagated Cavendish (Musa AAA Cv. 'Grande Naine'). Acta Hort., 447: 379-383.

Dougdoug, K.A. E. Harthi, H.M.S.E. Korkar, H.M. and Taha, R.M., 2007, Detection of somaclonal variations in banana tissue culture using Isozyme and DNA fingerprint analysis. J. Appld. Sci. Res., 3(7): 622-627.

Grillo, G. S. Martin, M. J. and Domenguez, A. M., 1998, Morphological methods for the detection of banana off-types during the hardening phase. Acta Hort., 490: 239-245.

Isabel, N. L. Tremblay, M. Michaud, F.M. Tremblay, and Bousquet, J., 1993, RAPDs as an aid to evaluate the genetic integrity of somatic embryogenesis-derived populations of Picea mariana (Mill.) B.S.P. Theo. Appld. Gent., 86: 81-87.

Israeli, Y. Reuveni, O. and Lahav, E., 1991, Qualitative aspects of somaclonal variations in banana propagated by in vitro techniques. Sci. Hort., 48: 71-78

Kaeppler, M. S. and Phillips, M., 1993, Tissue culture induced DNA methylation variation in maize. Pro. Natl. Acad. Sci., 90: 8773-8776

Martine, K. P. Pachathundikandi, S. K. Zhang, C. L. Slater, A. and Madassery, J., 2006, RAPD analysis of a variant of banana (Musa sp.) cv. Grande Naine and its propagation via 
shoot tip culture. In Vitro Cell Dev. Biol. - Plant, 42 (2): 188-192.

Martin, M.J. Grillo, G.S. and Dominguez, A.M., 1998, The use of randomly amplified polymorphic DNA (RAPD) for the study of genetic diversity and somaclonal variation in Musa. Acta Hort., 490: 45-454.

Prakash, D. P. Narayanaswamy, P. and S. S. SANDUR., 2002, Molecular diversity analysis in guava using RAPD markers. J. Hort. Sci. Biotech., 77 (3): 287-293.

Rani, V. Parida, A. and Raina, S.N., 1995, Random amplified polymorphic DNA (RAPD) markers for genetic analysis in micropropagated plants of Populus deltoides Marsh. Plant Cell Rep., 14: 459-462.

Rodrigues, P. H. V. Neto, A. T. Neto, P. C. and Mendes, B. M. J., 1998, Influence of the number of subcultures on somaclonal variation in micropropagated banana (Musa spp., AAA group). Acta Hort., 490: 469473.

Smith, M. K. and Drew, R. A., 1990, Growth and Yield characteristics of dwarf offtype recovered form tissue-cultured bananas. Australian J. Exptl. Agri., 30: 575-578

Smith, M. K., Hamile, S. D. Doogan, V. J. and Daniells, J. W. (1999). Characterization and early detection of an off-type from micropropagated Lady Finger bananas. Australian J.
Exptl. Agri, 39:

Venkatachalam, L. Sreedhar, R. V. and Bhagyalakshmi, N., 2007, Molecular analysis of genetic stability in longterm micropropagated shoots of banana using RAPD and ISSR markers. Electronic J. Biotech., 10(1): 0717-3458

Vidal, M. D. C. and Garcia, E. D., 2000, Analysis of a Musa spp. somaclonal variant resistant to Yellow Sigatoka. Plant Mol. Bio. Rep., 18: 23-31.

Vidya, R and Nair, A. S., 2002, Molecular analysis of somaclonal variation in Musa acuminata (AAA) cv. Red. Phytomorphology, 52(4): 293-300.

Walther, R. Ilan, A. Lerer, A. Durdevani, A. Khayat, E. Altman, A. and Ziv, M., 1997, Analysis of somaclonal variations in tissue cultured banana plants (Musa AAA Cv. 'Grand Naine'). Acta Hort., 447: 379-383.

Williams, J. G. K. Kubelik, A. R. Livak, K. J. Rafalski, J. A. and Tingey, S.V., 1990, DNA polymorphisms amplified by arbitrary primers are useful as genetic markers. Nucleic Acid Res., 18: 65316535.

Zaffari. G. R. Peres, L. E. P. Suzuki, R. M. and Kerbaury, G. B., 1998, Off-type micropropagated banana plants; endogenous levels of auxin, cytokinins and IAA-oxidase. J. Plant Growth Reg., 17(2): 59-61.

\section{How to cite this article:}

Shiddalingeswara, D., D.P. Prakash, Gajanana Kustagi and Nachegowda, V. 2018. Molecular Analysis of Micropropagated Banana Variants (Musa spp. 'AAA') Using RAPD Markers. Int.J.Curr.Microbiol.App.Sci. 7(07): 11-20. doi: https://doi.org/10.20546/ijcmas.2018.707.002 